\title{
THE ROLE OF A SPORTS EVENT IN CREATING A TOURIST OFFER IN VRNJAČKA BANJA
}

Tourism has huge and growing importance for the global economy, especially for the economies of developing countries. It represents the leading economic branch in many countries which is confirmed by the revenues they generate. However, there is an increasing emphasis on tourism events and a very large number of trips for satisfaction purposes that are associated with a particular event. Tourism is gaining great importance, but the expectations of tourists are also increasing, as well as their desire for specific experiences. In this way, these events contribute to attractiveness and to drawing tourists to certain places that they perhaps would never visit otherwise. They also have an influence on extending the stay at a destination and contribute to creating a reputation of a particular place, which enriches the tourist experience. The importance of organizing sports events is reflected in the fact that they can significantly affect the tourist offer of the destination. The subject of the paper is to examine the contribution of the organization and management of a martial arts manifestation to the tourist offer of a local community. The aim of the paper is to show that domestic consumption, although small, achieved in organizing such an event represents secure income for the destination.

Keywords: tourism, events, sports events, visitor, destination.

\section{Introduction}

Tourism events are a form of tourism that can contribute to the increase of the scope of tourism demand, especially according to the natural and anthropogenic values of a tourist destination or region. Namely, a man's need to be entertained, have fun, engage in activities, see new areas, habits, customs, make acquaintances, along with changing his living and working environment, has also influenced the

University of Kragujevac, Faculty of Hotel Management and Tourism in Vrnjačka Banja, Vrnjačka Banja, Serbia; elgibe@icloud.com

** University of Kragujevac, Faculty of Hotel Management and Tourism in Vrnjačka Banja, Vrnjačka Banja, Serbia; marija.lakicevic@kg.ac.rs

*** University of Kragujevac, Faculty of Hotel Management and Tourism in Vrnjačka Banja, Vrnjačka Banja, Serbia; danijela.durkalic@kg.ac.rs 
need to organize various, attractive events as part of a tourist offer of a certain area. Thus, rituals, fairs, manifestations, trade fairs, festivals, exhibitions, sports competitions, congresses, which, with their programs, represent a significant part of the tourist offer, were created. These are events that show various artistic, scientific, economic, sports and other achievements of a place or region, and have a tradition of being held. ${ }^{1}$ In this sense events serve not only to attract tourists, but also to help develop or maintain the identity of a community or region. ${ }^{2}$

Modern trends suggest that tourism and sport are the fastest growing industries in this century. For that reason, sports tourism has become one of the modern megatrends that have been growing in popularity in recent years and is making great profits. Sports events are characterized by creative and complex contents of sports for recreation and entertainment purposes, which take place according to a certain pre-prepared program, and they achieve tourist effects and goals and have socio-economic significance for the place or region where they are held. ${ }^{3}$ Accordingly, sports events represent a broad social phenomenon of today. They include different activities of organizers focused on the offer of a program, i.e. the games of the sports event organizers for a specific audience with the aim of achieving sports result. We can also observe them in a wider context, where recreation, entertainment, leisure and relaxation are primary, and not achieving sports results.

The event as a conscious and economically oriented human activity appeared a very long time ago with the emergence of ancient civilizations. However, since events cover a broad category, their occurrence is not related to the same time period. The first forms date from ancient times, i.e. six hundred years BC, when a King of China (Sui Yangdi) organized a one-month celebration for the people in his palace, where he gathered 30,000 entertainers who animated the audience; or in the second century BC when emperors of ancient Rome organized gladiator games and other spectacles in order to gain the support of the people (panem et circenses). ${ }^{4}$

Sports events have been known since the very beginnings of human civilization. It is known that the first Olympic Games were held in the far 776 BC in ancient Greece, in the temple of the goddess Hera. At the time of the Roman Empire, the sport and Olympic spirit of ancient Greece were replaced by fighting in arenas where, instead of athletes, gladiators fought for life or death. The development of modern sports is related to the year 1884 when the International Congress in Sorbonne took place in Paris and when the International Olympic

$1 \quad$ Bjeljac, Ž.,Štrbac, E. (2004):Turističke manifestacije na pravcu Dunavsko-moravskog koridora, Geografski institut Jovan Cvijić, Beograd.

2 Read more: Hall, C.M. (1992):Hallmark Tourist Events: Impacts, Management and Planning, BelhavenPress, London.

3 Bjeljac, Ž., (2006):Teorijsko-metodološke osnove manifestacionog turizma, Ministarstvo za nauku i zaštitu životne sredine, Beograd., p.45.

$4 \quad$ Stokar, Ž. (2006):Menadžment događaja, Kum, Beograd, p.1. 
Committee was formed. Sports and recreational events are sports manifestations of recreational character that can have a certain tourist potential as well. Thus, apart from the sports character, these recreations have cultural, historical, educational, social and tourist significance (direct acquaintance with a place and its natural and anthropogenic tourist values).

The events were probably created even before the appearance of money, but their development was undoubtedly followed after the establishment and acceptance of general equivalence since the non-material character and the conceptual basis of the events were not particularly favorable for natural exchange. ${ }^{5}$ It cannot be said with certainty which event occurred first in the economic sense. What is quite certain is that the economic phenomenon of events dates from the beginning of socially organized human life, but the economic study of the events, and especially of their management aspects, is of a recent date. The development of the events in economic sense also helped to solve the problem of employment of modern labor, and also reflected on the economic growth, primarily of developed market economies. Parallel to the development of contemporary events, their economic role and importance has increasingly been emphasized, which means that events represent a special offer within the service economy. The economic impact of events can be viewed as net economic changes in the local host community, which is the result of spending money that is related to an event. ${ }^{6}$

Today, the organization of events and conventions is an activity that has a turnover of 100 billion dollars and employs approximately 1.5 million people. The event segment has a high average annual growth rate of around $6 \%$ realized primarily because of business events. There are around a million different tourist events in the world today, and according to the data, up to $57 \%$ of travels for pleasure is related to a particular event. The management of the event sees tourists as a potential market and tourism as a key stakeholder and partner in achieving the desired success and creating the attractiveness of the event. ${ }^{8}$

In fact, they represent an opportunity for relaxation, a social or cultural experience that is different from everyday activities and experiences. ${ }^{9}$ They also represent one of the most exciting and fastest growing phenomena related to leisure, business and tourism. Thereat, they are clearly open to the public, Andrejević, A., Grubor, A. (2007):Menadžment događaja, Fakultet za uslužni biznis, Sremska Kamenica, str. 3.

6 Crompton, J. (1995):"Economic Analysis of Sports Facilities and Events: Eleven Sources of Misapplication", Journal of Sport Management, Vol. 9, No 1, p.14.

7 Wagen, L.V., Carlos, B. (2008):Event management-Upravljanje dogadjajima, Za turisticka, kulturna, poslovna, I sportska dogadjanja, Mate.d.o.o, Zagreb.

8 Getz., D. (2008):"Event Tourism: Definition, Evolution, and Research",Tourism Management,Volume 29, Issue 3, June 2008, pages 403-428.

9 Berridge, G. (2007):Events design and experience, Butterworth-Heineman, Elsevier, Oxford, p.5. 
with a central theme and limited by the opening and closing day. In this way, they belong to the most dynamic part of the tourism industry, which calls for applause. ${ }^{10}$ Events, both cultural and socio-economic, are creative and complex with certain significance for a place and with various program contents which realize the tourist goals and effects. ${ }^{11}$ In this way they show carefully created marketing ideas that are implemented through the established protocol in order to provide their participants with a unique, extraordinary, special or specific experience. $^{12}$

The value and attractiveness of the tourist offer of sports events depend on the characteristics of the place and the region in which they are held. The places with a more valuable tourist-geographical position, adequate attractiveness and tourist provisions (special infrastructure, information, supply, entertainment, sports activities, etc.) have more favorable conditions for organizing sports events.

\section{Literature Review}

In addition to the economic benefits, there are many other benefits for holding sporting events: sports events affect the positive image of the destination, attract visitors who are in that city for the first time, attract visitors who would not come without a sports event, increase visits during the off-season period, and lead to a re-visiting. ${ }^{13}$

A sports event is organized in order to meet the social needs of visitors. Visitors of a sports event do not represent a homogeneous group of people, because they can more or less be bound to the program of a sports event, but also to the actors, i.e. athletes, clubs or national teams. The audience of sports events is layered in terms of affirmation of their program, i.e. identification with the actors or domination in relation to the other group. ${ }^{14}$

Organizing great sports events is a very attractive undertaking for most of the major cities. Having the status of a host city usually brings special benefits

\footnotetext{
10 Matthew, D. (2008): Special Event Production, Elsevier's science, Burlington.
}

11 Ožegović, S. (1979):”Turističke manifestacije”, Turizmologija - Zbornik stručnih i naučnih radova, Beograd, br.10, pg. 49-56.

12 Fermevc, K. (2011):Značaj organizacije velikih događaja za razvoj turizma, master rad, Ekonomski fakultet, Univerziteta u Beogradu, p. 4.

13 Stone, M., Petrick, J. (2016): “Site Selection Factors for Youth Sport Tournaments”,Tourism Travel and Research Association: Advancing Tourism Research Globally, 2012 TTRA International conference, p.17, http://scholarworks.umass.edu/cgi/viewcontent. cgi?article $=1813$ \& context $=$ ttra $(10.09 .2017)$

14 Kostić, S. (2016): “Modeli planiranja sportskih događaja”, Menadžmenti sport, Zbornikradova, XI Međunarodna naučna konferencija:Management, Sport, Olympism, Beograd, str. 89. 
that cannot or should not always be calculated in terms of money. Occasionally, the image is more important, and sometimes it is enough to be in a good company. ${ }^{15}$

Figure 1. Classification of sports events ${ }^{16}$

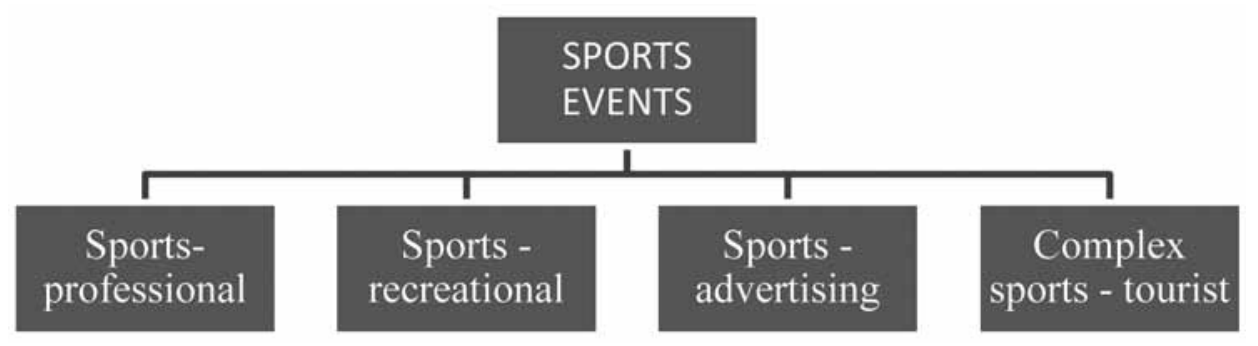

The needs of the local population in the field of sports are met in the municipality and in the city as local self-government units, and the means to meet these needs are provided from their budgets and can be used, inter alia: for the construction, holding and use of sports facilities in which the needs in the area of sports are met, in the municipality, or in the city; financing the activities of sports organizations established by the municipality, i.e. the city and the realization of programs, or parts of programs of other organizations contributing to meeting the needs in the field of sports at the level of the municipality or city; organization and holding of sports competitions and events of importance for the municipality or city; providing work conditions for sports professionals in organizations in the field of sports in the territory of the municipality or city. ${ }^{17}$

The first step towards a new facility is usually a statement of a team that its existing facilities are „inadequate”. Inadequacy does not usually relate to accommodation, structural integrity or aspects of the event, but to the fact that stadiums that were built more than a decade ago do not include luxurious lodges, club seats, catering facilities and advertising opportunities that generate cash inflows from high-paying fans. In other words, although existing facilities are not physically outdated, they are economically outdated. ${ }^{18}$ Numerous studies of travelling sports events have dealt with major events or marking events,

15 Włodarczyk, B. (2016): "Łódź as an Arena of Grand Sports Events: Selected Examples”, Tourizm2016,26(1), DOI:10.1515, ISSN: 2080-6922; 0867-5856, p. 49-59.

16 Bjeljac, Ž., (2006):Teorijsko-metodološke osnove manifestacionog turizma, Ministarstvo za nauku i zaštitu životne sredine, Beograd., p.45.

17 Petrović L., Životić D. (2013): “Uloga i značaj lokalne zajednice za razvoj sporta”, IX Međunarodna konferencija: Menadžment u sportu, Zbornik radova 1, str. 218.

18 Siegfried, J., \& Zimbalist, A. (2000): "The economics of sports facilities and their communities", The Journal of Economic Perspectives, 14(3), 95-114. 
rather than small events, which can also benefit one region. ${ }^{19}$ One of the reasons why interest in maintaining major sports events has grown is that just as they are considered to be useful for selling all kinds of commercial products, they are also considered valuable promotional opportunities for cities and regions, representing their attractions to the global audience and helping to attract tourism and foreign investment. ${ }^{20}$

When a sports event is transformed into a tourist product, the ranking of a given event is very important because it allows an estimate of its size and through that the number of potential tourists (supporters) interested in coming to a given city. ${ }^{21}$ In the practice of managing sports events, the situations in which organizers meet the needs and requirements of all visitors are rare. Organizers achieve the goals of a sports event in meeting the needs, demands and expectations of a precisely determined segment of the sports market. Generally speaking, the goals achieved in the market segment can be divided into two basic groups: the profit goals of a sports event and non-profit, i.e. sports goals. ${ }^{22}$ All decisions made by an organization should be recognized as fair and equitable to all or they will have a negative impact on the community. In a study of judges, for example, the judges were very concerned about whether they were treated fair in terms of the quality of the games they were assigned, of the distance to the venue and of partners assigned to them. When they thought they were treated fairly, the community was strengthened. When they felt they were not treated fair, the community was strongly subdued and people felt outraged and angry. This means that all decisions made by the organization should be recognized as fair and equitable to all or they will have a negative impact on the community. One of the more interesting findings in terms of community research in sport is the role of competition in building a community. While some people might argue that the competition is limited to sports, it is also possible that it can be used in non-sport related conditions to build a sense of community. ${ }^{23}$

19 Stone, M., Petrick, J. (2016): “Site Selection Factors for Youth Sport Tournaments", Tourism Travel and Research Association: Advancing Tourism Research Globally, 2012 TTRA International conference, p.17, http://scholarworks.umass.edu/cgi/viewcontent. cgi? article $=1813 \&$ context $=$ ttra $(10.09 .2017)$

20 Horne, J. (2007): “The four 'knowns' of sports mega-events”, Leisure studies, 26(1), 81-96.

$21 \quad W ł o d a r c z y k$, B. (2016): "Łódź as an Arena of Grand Sports Events: Selected Examples”, Tourizm2016,26(1), DOI:10.1515, ISSN: 2080-6922; 0867-5856, p. 49-59.

22 Kostić, S. (2016): “Modeli planiranja sportskih događaja”, Menadžmenti sport, Zbornikradova, XI Međunarodna naučna konferencija:Management, Sport, Olympism, Beograd, str. 89.

23 Warner, S., Dixon, M. (2016): “Connecting It All: Creating Community in Sport and Entertainment”,Sport \& Entertainment Review, 2016, 2 (20) p.45-50, http://thescholarship. ecu.edu/bitstream/handle/10342/6063/warner\%20dixon $\% 202016 \% 20$ connecting\%20 it\%20all.pdf?sequence $=1$ \&isAllowed $=y(10.10 .2017)$ 


\section{Methodology}

For the purposes of this paper, a survey was conducted on the attitudes of sports workers and athletes about the sports tourism of Vrnjačka Banja. A total of 21 polls were collected. All respondents are participants in a boxing competition, specifically the regional round of the Šumadija League, which was held this time in the sports hall "Vlade Divac" in Vrnjačka Banja. According to the rules of the international boxing federation "AIBA" (Association Internationale de Boxe Amateure), for holding a boxing competition, in addition to competitors or "boxers", competing in 10 to 13 weight categories depending on the age, and their coaches, other participants are also needed which are necessary for holding matches, consisting of: a minimum of five scoring judges, one referee in the ring, a timekeeper, a supervisor of the competition, a doctor, a computer operator, a speaker, a cameraman, a photojournalist and, of course, an audience. All the mentioned participants of this competition were questioned, answering eight questions of the closed type, based on which we attempted to get the answers related to the hypotheses. In the third regional round of the Sumadija league, according to the data obtained from the organizer of the Goč Boxing Club competition, 32 competitors from 9 different clubs took part, aside from the aforementioned host club. At this sports event, 60 spectators attended according the same data source.

Table 1 presents the social demographic characteristics of the respondents. In it, in the first column the status of the participants in the competition is entered; the second column lists the gender of the participants; in the third column the age structure of the respondents is presented, and the fourth column lists their working status in private life. Most respondents are male, and only two women were questioned and they both participate as competitors in this round of the Šumadija league. It can be seen that competitors comprise the largest number of participants who answered the questions asked. They also make the largest number of participants in the entire event, not including the audience. They are, on average, the youngest among respondents with an average of 16.5 years and are mostly pupils and students. The second largest group were the judges, who have an average of 43 years and are mostly employed. The oldest among the respondents are coaches with an average of 50.4 years. The survey also included the supervisor of the competition and the doctor on duty. The surveyed participants in the regional round of Šumadija in Boxing are 35.95 years old on average and their working statuses are as follows: 8 employees, 1 private entrepreneur, 4 pensioners, 3 students, 4 pupils and only one unemployed person. 
Table 1. Characteristics of respondents

\begin{tabular}{|c|c|c|c|c|}
\hline & PARTICIPANT & GENDER & AGE & EMPLOYMENT STATUS \\
\hline 1. & Competition supervisor & male & 66 & Pensioner \\
\hline 2. & Doctor & male & 35 & Employed \\
\hline 3. & Judge & male & 69 & Pensioner \\
\hline 4. & Judge & male & 61 & Employed \\
\hline 5. & Judge & male & 37 & Employed \\
\hline 6. & Judge & male & 37 & Employed \\
\hline 7. & Judge & male & 33 & Employed \\
\hline 8. & Judge & male & 71 & Student \\
\hline 9. & Coach & male & 58 & Pensioner \\
\hline 10. & Coach & male & 50 & Pensioner \\
\hline 11. & Coach & male & 39 & Employed \\
\hline 12. & Coach & male & 34 & Entrepreneur \\
\hline 13. & Coach & male & 26 & Employed \\
\hline 14. & Contestant & female & 24 & Employed \\
\hline 15. & Contestant & male & 19 & Student \\
\hline 16. & Contestant & male & 18 & Student \\
\hline 17. & Contestant & 18 & Unemployed \\
\hline 18. & Contestant & 14 & Pupil \\
\hline 19. & Contestant & 13 & Pupil \\
\hline 20. & Contestant & & 12 & Pupil \\
\hline 21. & ontant & male & 34 & \\
\hline
\end{tabular}

Source: Author's own research work

All respondents are participants of this competition and form its integral part, so it can be said that they represent the minimum number of participants in a boxing event. 


\section{Results}

When asked whether they were visiting Vrnjačka Banja for the first time, 15 respondents answered that they often came, 4 respondents had visited it once before, and only 2 of them were visiting this tourist place for the first time. The supervisor, the doctor, all the examined coaches and most of the judges often visit Vrnjačka Banja, only the competitors said that they had visited it once before.

Chart 1. Structure of the answer to the question "Is this the first time you have visited Vrnjackka Banja?" presented as the bar chart.

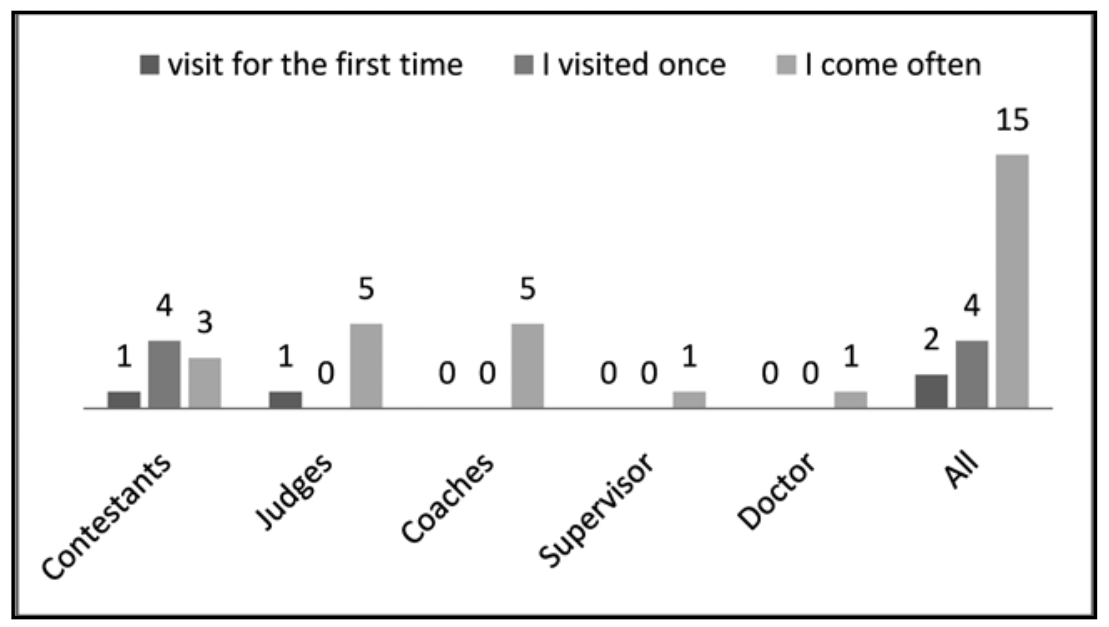

Source: Author's own research work

When asked whether they had visited other places in Vrnjačka Banja, 15 respondents answered that they had had a walk through the park of Vrnjačka Banja, 6 respondents visited mineral springs, 5 visited the Wellness centers, 11 visited the catering facilities, while 2 respondents answered that they have only stayed in the sports hall. The Vrnjačka Banja Park was mostly visited by competitors, coaches and judges. The catering facilities were mostly visited by judges and coaches. 
Chart 2. The structure of the response about a visit to a place other than the sports hall is represented as the bar chart.

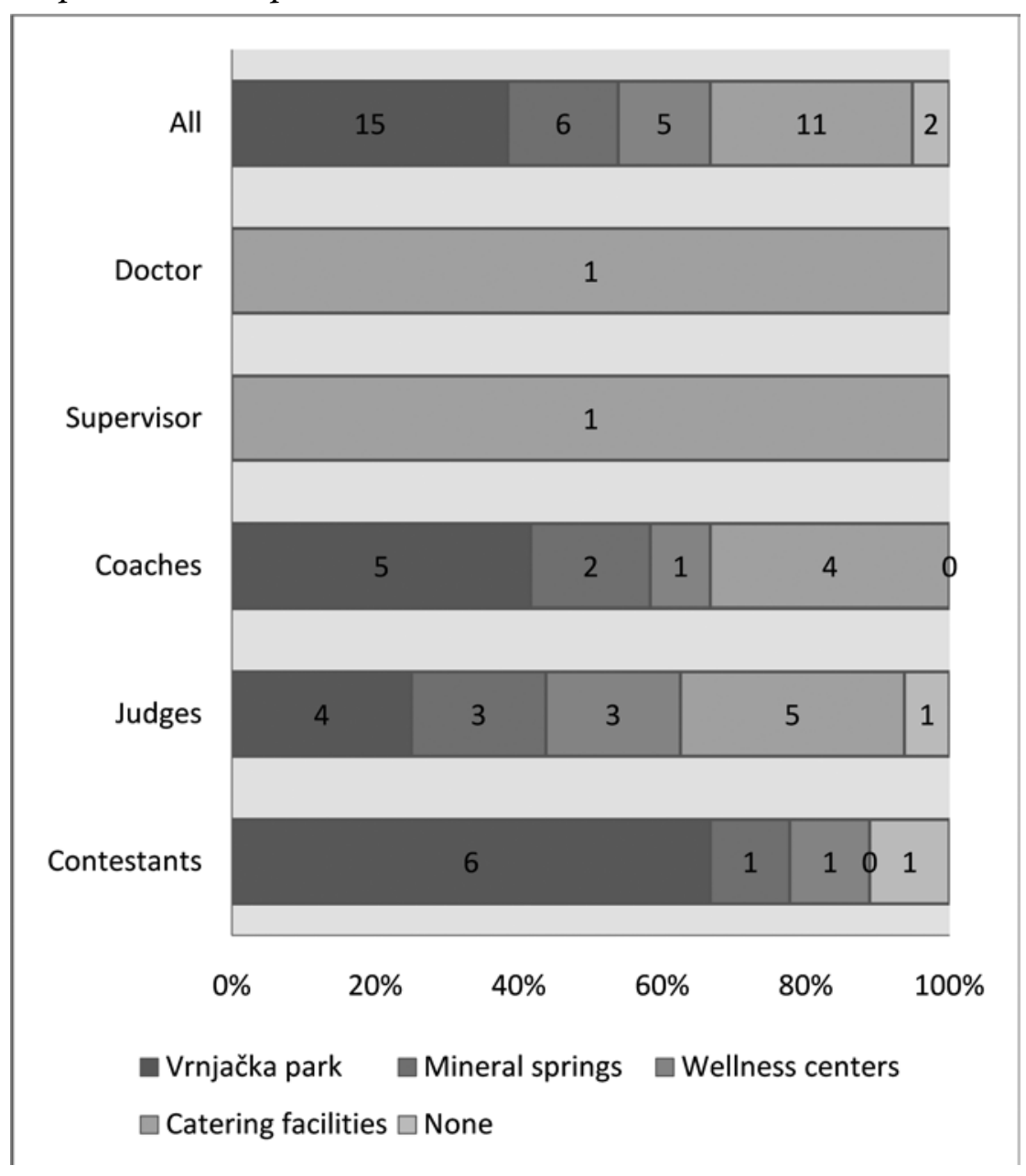

Source: Author's own research work

When asked whether they had lunch or dinner in Vrnjačka Banja, 11 respondent participants answered that they did have lunch, 7 had two meals, while 3 of them did not have any meals in Vrnjačka Banja. The competitors, the supervisor and the doctor answered that they had lunch, while the coaches and judges had lunch and dinner. Two competitors and one judge did not have any meals in Vrnjačka Banja. No one of the respondents had dinner as the only meal. 
Chart 3. The structure of the answer to the question about lunch and dinner during the stay is presented as the bar chart.

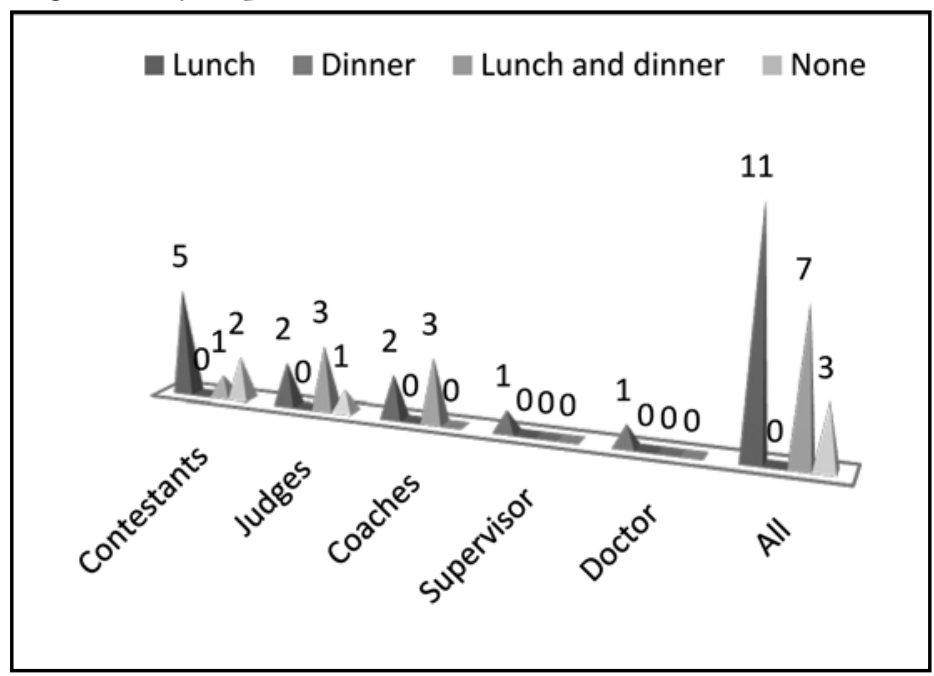

Source: Authorss own research work

When asked whether they visited cafes or restaurants in Vrnjačka Banja, one contestant and one judge gave a negative answer, the remaining 19 responded positively.

When asked whether they bought something during the stay in Vrnjačka Banja, 9 respondents answered that they did not buy anything; the other 12 bought one or more products. Most of them bought a souvenir, clothing articles (shoes, clothes, sports equipment...) two of them had bought something else, while jewelry (gold, costume jewelry, a watch...) was bought only by one person. The contestants generally did not buy anything, and only one of them bought a souvenir. The judges bought clothes and souvenirs, while two of them did not buy anything and one replied that he had bought something else. As far as the coaches are concerned, each of them bought something, and most of them bought souvenirs. The supervisor of the competition bought a souvenir and the doctor bought clothes.

When asked whether they liked Vrnjačka Banja, none of the respondents answered negatively, 14 were delighted with Vrnjačka Banja, while 7 were quite satisfied. 6 competitors were delighted by this tourist destination, as well as 5 judges, a coach, the supervisor and the doctor. 4 coaches, 2 competitors and 1 referee were quite satisfied. 
Chart 4. Structure of the answers to the question «Did you like Vrnjačka Banja?» is presented as the bar diagram.

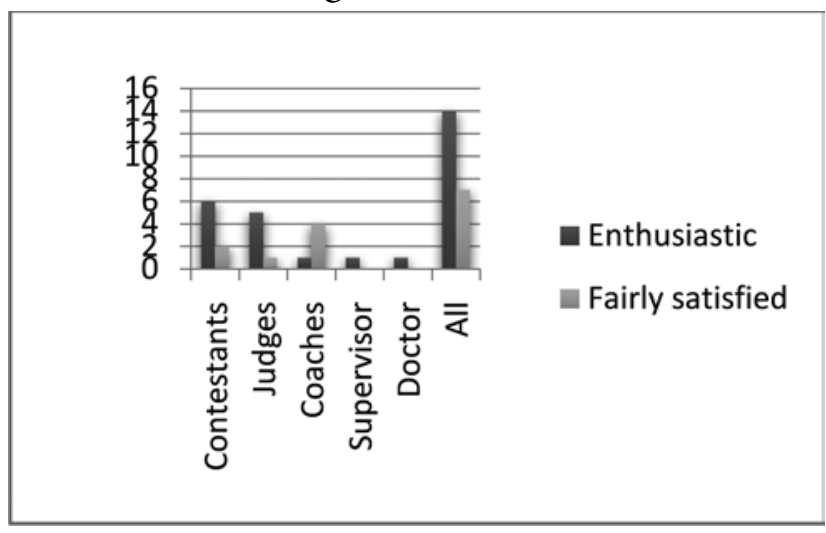

Source: Authorss own research work

The conducted analyses confirm that Vrnjačka Banja is a well-known and visited tourist place, i.e. that a greater number of respondents have already been to the most visited spa in Serbia. A small number of respondents visited it for the first time, precisely due to this sports event. Most enjoyed the natural beauties of Vrnjačka Banja, walking along the spa park and the promenade, and using catering services. The conducted survey confirms that sports events can attract a certain number of visitors, which is very important if events are organized out of season so that the tourist demand during all the months throughout the year is evenly distributed. A more professional approach to organizing events is needed in order for a particular community to create its identity, attract visitors and make significant revenues.

When asked whether the current stay would affect visiting Vrnjačka Banja again, all respondents replied that they would come to visit the spa privately next time. Furthermore, they will also recommend Vrnjačka Banja to their relatives, friends and neighbors which will create a positive image with potential tourists about «the queen of spa tourism» in Serbia.

\section{Conclusion}

Holding sports events has an evident impact on Vrnjačka Banja. The obtained data of the survey, which was processed for the purposes of this paper, shows on participants of the boxing competition that the majority of the respondents, apart from participating in the organization of the competition, use their time to visit Vrnjačka Banja Park and catering facilities, while making certain tourist expenditures. However, given the fact that the capacity of the sports center 
Vrnjačka Banja, the capacity of the sports hall "Vlade Divac" is 1300 seats, it can be said that 60 spectators at the regional boxing round of Šumadija are a very 'poor' audience.

We can conclude that a strategic approach is needed for this activity, because of the positive effects of events that tourists bring by visiting exceed their economic benefits, leading to the strengthening of social capital, the development of the region and a significant improvement in the quality of life of people in these areas. Due to the lack of other tourist attractions in the off-season, events represent the fastest and most cost-effective way of building image and creating demand in these areas. However, the reliance of many municipalities on manifestation tourism as the main source of income has conditioned the emergence of numerous events and festivals. Still, enormous competition and saturation of the market have led to failure, with the key factors of it being: lack of financial resources, inadequate promotion, inadequate strategic planning and incompetence of personnel for this tourist product. For this reason, it is necessary to improve the quality of the events in terms of originality, attractiveness and content with the aim of achieving a competitive advantage.

The conducted analysis shows that the local tourist communities have realized that they cannot rely solely on what nature has given them, but that the specifics of their region should be presented with interesting events. However, the most common role of organizers of events in our country belong to local communities whose members are often not qualified, leading to numerous problems at all stages of development of the events. Therefore, it is necessary to deal with the management and development of the events while preserving the authentic characteristics of the site.

\section{Literature}

- Andrejević, A., Grubor, A. (2007): Menadžment događaja, Fakultet za uslužni biznis, Sremska Kamenica, str. 3.

- Berridge, G. (2007): Events design and experience, Butterworth-Heineman, Elsevier, Oxford, str. 5.

- Bjeljac, Ž., (2006): Teorijsko-metodološke osnove manifestacionog turizma, Ministarstvo za nauku i zaštitu životne sredine, Beograd., str.45.

- Bjeljac, Ž., Štrbac, E. (2004): Turističke manifestacije na pravcu Dunavskomoravskog koridora, Geografski institut "Jovan Cvijić", Beograd.

- Crompton, J. (1995): "Economic Analysis of Sports Facilities and Events", Eleven Sources of Misapplication, Journal of Sport Management, Vol. 9, No 1, str.14.

- Fermevc, K. (2011): Značaj organizacije velikih događaja za razvoj turizma, master rad, Ekonomski fakultet Univerziteta u Beogradu, str. 4. 
- Getz., D.(2008): “Event Tourism: Definition, Evolution, and Research”, Tourism Management, Volume 29, Issue 3, June 2008, p. 403-428.

- Hall, C.M. (1992): Hallmark Tourist Events: Impacts, Management and Planning, Belhaven Press, London.

- Horne, J. (2007): „The four 'knowns' of sports mega-events”, Leisure studies, No.26, Volume 1, p. 81-96.

- Kostić, S. (2016): "Modeli planiranja sportskih događaja", Menadžmenti sport, Zbornik radova, XI Međunarodna naučna konferencija: Management, Sport, Olympism, Beograd, str. 89.

- Matthew, D. (2008): Special Event Production, Elsevier's science, Burlington.

- Ožegović, S. (1979): “Turističke manifestacije”, Turizmologija, Zbornik stručnih i naučnih radova, Beograd, br.10, str. 49-56.

- Petrović L., Životić D. (2013): «Uloga i značaj lokalne zajednice za razvoj sporta», IX Međunarodna konferencija: Menadžment u sportu, Zbornik radova 1 , str. 218.

- $\quad$ Siegfried, J., \& Zimbalist, A. (2000): “The economics of sports facilities and their communities", The Journal of Economic Perspectives, No.14, Volume 3, p. 95-114.

- Stokar, Ž. (2006): Menadžment događaja, Kum, Beograd, str. 1.

- Stone, M., Petrick, J. (2016): "Site Selection Factors for Youth Sport Tournaments", Tourism Travel and Research Association: Advancing Tourism Research Globally, 2012 TTRA International conference, p. 17,

- http://scholarworks.umass.edu/cgi/viewcontent.cgi?article=1813むcontext=ttra (10.09.2017)

- Wagen, L.V., Carlos, B. (2008): Event management - Upravljanje dogadjajima, Za turisticka, kulturna, poslovna, i sportska dogadjanja, Mate.d.o.o, Zagreb.

- Warner, S., Dixon, M. (2016): "Connecting It All: Creating Community in Sport and Entertainment”, Sport \& Entertainment Review, 2016, 2(20)p.45-50, http://thescholarship.ecu.edu/bitstream/handle/10342/6063/warner\%20 dixon\%202016\%20 connecting\%20it\%20all.pdf?sequence=1\&isAllowed =y $(10.10 .2017)$

- Włodarczyk, B. (2016): „Łódź as an Arena of Grand Sports Events: Selected Examples», Tourizm 2016, 26 (1), DOI:10.1515, ISSN: 2080-6922; 0867-5856, p. $49-59$.

- http://www.aiba.org/aiba-technical-competition-rules/(09.10.2017)

- http://www.scvrnjackabanja.rs/objekti/sportska-hala (09.10.2017) 


\section{ULOGA SPORTSKOG DOGAĐAJA U KREIRANJU TURISTIČKE PONUDE VRNJAČKE BANJE}

Turizam ima veliki i rastući značaj za globalnu ekonomiju, naročito za ekonomije država u razvoju. On predstavlja vodeću privrednu granu u mnogim zemljama i to potvrđuju prihodi koje one ostvaruju. Međutim, sve se više ističe turizam događaja $i$ veoma veliki broj putovanja proisteklih iz zadovoljstva, a koja su povezana sa određenim događajem. Turizmu se pridaje veliki značaj, ali i očekivanja turista su sve veća, kao $i$ njihova želja za specifičnim doživljajima. Na taj način doprinose atraktivnosti i privlačenju turista u određena mesta koja možda nikada ne bi posetili. Takođe, utiču na produžetak boravka u destinaciji $i$ doprinose kreiranju imidža određenog mesta čime obogaćuju turistički doživljaj. Značajnost održavanja sportskih manifestacija ogleda se u činjenici da one mogu uticati na turističku ponudu destinacije. Predmet rada je sagledavanje doprinosa pri organizovanju i održavanju manifestacije borilačkih veština na turističku ponudu lokalne zajednice. Cilj rada jeste da ukaže da domaća potrošnja koja se ostvaruje pri organizovanju jednog ovakvog događaja predstavlja sigurne prihode destinacije.

Ključne reči: turizam, događaji, sportske manifestacije, posetilac, destinacija. 